\title{
Using New Media and Social Media in Disaster Communication
}

\author{
Dhyah Ayu Retno Widyastuti ${ }^{1, a)}$ \\ ${ }^{1}$ Communication Department, Universitas Atma Jaya Yogyakarta, Indonesia \\ a) author correspondence: dhyah.ayu@uajy.ac.id
}

DOI: https://doi.org/10.18196/jkm.12074

\section{Article Info}

Article history:

Received 24 Jun 2021

Revised 7 Sep 2021

Revised 4 Oct 2021

Accepted 14 Oct 2021

\begin{abstract}
New media and social media have changed the frame of communication that appears quickly, is interactive, and has no geographical boundaries. The media plays an essential role in disseminating accurate and responsible information in a disaster situation. The strategy of using communication media will reduce the impacts arising from disasters in the mitigation, preparedness, response, and recovery phases. Through a literature review, the author presents disaster communication, strategies, and using media in disasters. The research use case studies are the natural disaster of Mount Merapi and the Covid-19 pandemic to represent non-natural disasters. The results of the analysis show that sensitivity to the situation is an adequate response in a disaster. Furthermore, new media and social media tend to be sufficient as the primary source of information for the public, coordination, and fundraising. The effectiveness of media use in the Merapi disaster is the beginning of new media and social media in disaster communication in Indonesia. This media is also used in disaster management during the COVID-19 pandemic. The use of media in both case studies is considered adequate to reduce the negative impacts arising from the disaster. It is hoped this idea will contribute to disaster communication studies.
\end{abstract}

Keywords: Covid-19; Disaster Communication; Media; Merapi.

\section{ABSTRAK}

Keberadaan media baru dan media sosial telah mengubah bingkai komunikasi yang muncul dengan cepat, bersifat interaktif, hingga tanpa batas geografis. Dalam situasi kebencanaan, media berperan penting dalam menyebarkan informasi yang akurat dan bertanggung jawab. Strategi penggunaan media komunikasi akan mengurangi dampak yang timbul dari bencana baik fase mitigasi, kesiapan, respon, dan pemulihan. Melalui literature review, penulis menyajikan konsep mengenai komunikasi bencana, strategi komunikasi kebencanaan, dan pemanfaatan media dalam kebencanaan. Studi kasus ditentukan adalah bencana alam Gunung Merapi dan pandemi Covid-19 sebagai representasi bencana non-alam. Hasil analisis menunjukkan terhadap situasi merupakan respons efektif dalam kebencanaan. Media baru dan media sosial cenderung efektif sebagai sumber informasi utama bagi masyarakat, koordinasi, dan penggalangan dana. Media ini juga dimanfaatkan dalam manajemen bencana selama pandemi COvid-19. Efektivitas penggunaan media pada bencana Merapi menjadi awal penggunaan media baru dan media sosial pada komunikasi bencana di Indonesia. Pemanfaatan media pada kedua studi kasus dianggap efektif sehingga mampu mengurangi dampak negatif yang timbul dari bencana. Harapannya gagasan ini berkontribusi pada studi mengenai komunikasi bencana.

Kata Kunci: Covid-19; Komunikasi Bencana; Media; Merapi. 


\section{INTRODUCTION}

Disaster communication has undergone a shift along with the development of media. The internet, which began to be used widely in the early 2000s, changed how information was collected and distributed (Haddow and Haddow, 2014). In addition, new media and social media are rapidly growing, especially with the ease of access provided by smartphones and tablets. Finally, internetbased media has become a communication medium that is widely used and an essential component of most people's lives (Yates, D., \& Paquette, 2011). This platform offers various features to create message content and build a comfortable socialization space for its users.

The media has a compelling strategic mission in disaster communication by providing timely and accurate information to the public in the mitigation, preparedness, response, and recovery phases. In a disaster, the media plays a significant role in communicating with the public. The communication system during the disaster phase uses various mobile technology-based platforms and websites such as short message services or SMS and blogs and mixed social media such as Twitter, Facebook, Viber, WhatsApp, Instagram, and YouTube (Topno, 2016).

New media platforms and social media are emerging as new ways of providing instant information during the disaster phase. In general, the media is used to update information and spread public awareness of disaster conditions, create communities and volunteers to manage aid, raise funds, and monitor and provide knowledge on all situations that occur, including disaster status reports (Topno, 2016).

As a new face in disaster management, new media and social media can present new data sources and real-time information from the field. The use of social media in disasters, such as Twitter, was first during the Haiti earthquake in 2010 (Holdeman, 2016). The Haiti earthquake was an event that killed 100,000 people and left the center of the capital in ruins and political instability. Recovery efforts required external assistance from other countries and international organizations. Due to the weakness of the organization, many aspects of rescue are absent. Then one of the steps taken was the deployment of the Ushahidi platform during the earthquake. Ushahidi is a collaborative mapping system that relies on SMS and social media for information, enabling the collection of reports on people trapped in buildings and those in need of health care and humanitarian supplies (Holdeman, 2016).

Besides, tracking accurate hashtags and keywords is crucial in exchanging information (Harihar, 2015). In addition, in 2016, social media was used for disaster communication during Tropical Cyclone Winston (Finau et al., 2018). Tropical Cyclone Winston is the strongest typhoon in the world. On February 20, 2016, this disaster occurred in Fiji and caused a total loss of US\$460 million, including damage to private property, infrastructure, and disruption of water, electricity, and sanitation (Robie and Chand, 2017).

Communication strategies using new media and social media are an alternative form of communication in crises and disasters. Decisions on new media and social media are based on a high trend consensus on the current number of networked media users. Data shown by We Are Social as of January 2020, the number of internet users is 175.4 million. More than half of the population in Indonesia includes WhatsApp users by $84 \%$, Facebook by $82 \%$, and Instagram by $79 \%$ of the total population (Jayani, 2020). Even Facebook users reached 2.1 billion people as of December 2019 (Clinten, 2019).

An effective disaster communication strategy will reduce the negative impacts of disasters (Haddow \& Haddow., 2014; Sena \& Kifle, 2006). A communication network helps the community in reducing disaster risk (Wardyaningrum, 2019). In addition, effective use of media will affect behavior change for its users. Therefore, the author uses the Uses and Gratification Theory as a reference in analyzing the reality of optimizing the use of new media and social media in disaster communication management.

The case study used is the Merapi volcano disaster to represent natural disasters. In contrast, the Covid-19 pandemic means non-natural disasters. These two disaster situations have significant implications for the dynamics of people's lives. First, Merapi volcano is an active volcano with a cycle of eruptions within a certain period. The outbreak of Merapi volcano has a high level of disaster threat (Qoidah and Widowati, 2020). Since the last eruption from May 21, 2018 to 2021, the volcano is still in an alert status. This condition causes several residential areas on the slopes of the mountain to be affected by ash rain. The perceived impacts include damage to physical infrastructure to the psychological state of the community, both chronic and mild. Some disaster risk management is 
carried out, such as community-based disaster management (Qoidah and Widowati, 2020), community radio and social networks (Hafida and Siti, 2018), communication media such as local and national TV, internet media, broadcast radio, and others (Lestari and Agung, 2012).

The second case study is the Covid-19 pandemic caused by the SARS-CoV-2 (Severe Acute Respiratory Syndrome Corona-virus 2) at the end of 2019, impacting most of the representation and social practices of the world's population (Billy, 2020). The pandemic, which started in China, was declared a national disaster by the Indonesian government in March 2020 and will continue in 2021. Restrictions on activities outside the home have encouraged changes in people's lives. Dissemination of information and fulfillment of community needs is primarily online. Media information has a significant role during the pandemic. However, various consequences follow in the use of onlinebased information media, such as hoaxes and infodemics (Hua and Shaw, 2020). For instance, excessive and unproven information is present to confuse the public during the Covid-19 disaster (WHO \& PAHO, 2020).

The disasters, both the eruption of Merapi volcano and the Covid-19 pandemic, illustrate the role of the media in disaster communication. There is a shift in media use in dealing with this situation, starting from conventional media in the case study of Merapi to switching through new media and social media. The Covid-19 pandemic, which began during the transformation of information and communication technology changes, underpin new media and social media in handling this situation. On the other hand, other challenges need to be overcome in the use of this media. This reason underpins the researcher in determining the case study.

This research emphasizes identifying the use of new media and social media in natural and nonnatural disasters that have not been found in the previous study. Existing research presents the effectiveness of using community radio in natural disasters and communication management in emergency response in general conditions. Furthermore, in this research, the focus of the studies includes (a) strategic planning in disaster communication in Indonesia; (b) toward new media and social media in disaster strategies; and (c) the effective use of new media and social media in disaster communication. It is hoped that the research will increase new insights and knowledge regarding new media and social media in strategic planning and disaster communication studies.

\section{METHOD}

This research is qualitative descriptive. Researchers use literature reviews to find various ideas and theories to answer research questions. The literature review is relevant as a methodology for exploring collective evidence in a research area and providing an overview of research problems on a particular topic (Snyder, 2019).

In this research, the literature review is done to provide a basis for building a conceptual understanding of disaster communication strategies and mapping relevant case studies. Conceptually, the researcher could choose literature reviews in systematic reviews, semi-systematic reviews, and integrative reviews. This study uses a systematic literature review as a research method and process to identify and critically assess relevant research. In addition, it aims to collect and analyze data from the study (Liberati, 2009). Finally, a systematic review allows the researcher to identify empirical evidence that fits the defined case study criteria.

The case studies selected in the survey were natural disasters at Mount Merapi and non-natural disasters, namely the Covid-19 pandemic. In addition, researchers reviewed articles and journals related to this theme so that the background emerged and became a critical evaluation in this study. The natural disaster of Merapi volcano was chosen because it describes eruptions that occur periodically and cause several impacts on the community. Meanwhile, the Covid-19 pandemic is an issue faced by the community as a national disaster in Indonesia since 2020. These two types of disasters have a dynamic tendency to describe the condition of disaster communication. Disaster communication management is carried out to solve problems, including new media and social media in disaster communication. The Merapi volcano disaster has pioneered the use of new media and social media in disaster management in Indonesia. This utilization also continues in the Covid-19 pandemic, where new media and social media are the dominant needs in people's lives.

The presentation of the data is carried out in a descriptive narrative manner from each case study. Through a gradual process, it is hoped that this literature review can provide new knowledge on disaster communication and media use for achieving the effectiveness of disaster communication strategies. 


\section{RESULT AND DISCUSSION}

Disaster is an essential issue in development communication in Indonesia, even in various countries, because disasters continue to increase in the early 21 st century. This event is a severe disruption of functioning that involves a community of people and has widespread human, material, economic and environmental impacts that exceed the ability of the affected community to use its resources (Bradley et al., 2014). Disasters that occur can be caused by several factors, both natural and non-natural, such as the occurrence of shifts in the earth's plates, environmental management or some human actions that intentionally ignore the balance of nature (Beach, 2010; Sena \& Kifle, 2006; Shibuya, 2020).

Disaster emergency planning began to develop after the understanding of vulnerability due to disasters started to be realized. This planning is part of efforts in anticipating a rice and overcoming problems in disaster areas (Alexander, 2015). The steps taken include initial preparation, coordination, and evacuation and emergency operations involving the community, government, NGOs, and academics (Victoria, 2002).

The approach to disaster communication has also shifted. Various types of media, including mass media, community media, and even the internet, provide a comprehensive source of knowledge and information and serve as tools for development, and complement the approach to disaster communication. The result of information and communication technology at the beginning of the $21^{\text {st }}$ century has positive consequences on disaster communication, such as using new media and social media in strategic planning of disaster communication.

\section{Strategic Planning of Disaster in Indonesia}

Communication strategy is a way of coordinating administrative functions in all fields of science by involving the organization as a whole and communicating intentionally to advance its mission (Hallahan, 2017). The emphasis is on applying communication strategies and how an organization functions as a social actor to advance its mission. Strategy is a linear outcome, a rational-analytic process, which includes situation analysis, implementation of decision-making, strategy formulation, and evaluation. Critically there is a view that it is impossible to determine the ultimate goal of a strategy in advance (Frandsen, F. and Johansen, 2017). Pitt \& Emili (2017) assert three possibilities for communication strategies: success, problems, and failure.

The success of a strategy happens when the communication matches the initial planning. However, it could inevitably be problematic or even fail when the enormity of the disaster does not check the initial predictions. Even the tendencies of strategic planners tend to be blamed.

An effective disaster communication strategy provides timely and accurate information to the public in all four phases of emergency management. The mitigation phase promotes strategies, technologies, and actions to reduce the loss of life and property in future disasters. The readiness phase is related to communicating preparedness messages that encourage and educate the public to anticipate disaster events. The response phase provides the community with announcements, warnings, evacuations, and situation reports about the ongoing disaster. While the recovery phase is more concerned with giving disaster-affected individuals and communities information on registering and receiving disaster assistance (Haddow \& Haddow, 2014).

A successful disaster communication strategy is built on a set of fundamental principles. Haddow \& Haddow (2014) explore the principles, including (a) Focus on community needs (b) Commit to effective communication (c) Make communication an integral part of all disaster planning and operations (d) Be transparent in touch (e) Ensure that the information provided is accurate (f) Deliver information on time (g) Accessible personal contacts are available (h) Create an emotional connection with the community (i) Building partnerships between the media and the "first informant" community.

This principles become the primary direction of effective communication in disaster communication. The flow of information in strategic disaster management is shown in Figure 1 below. 


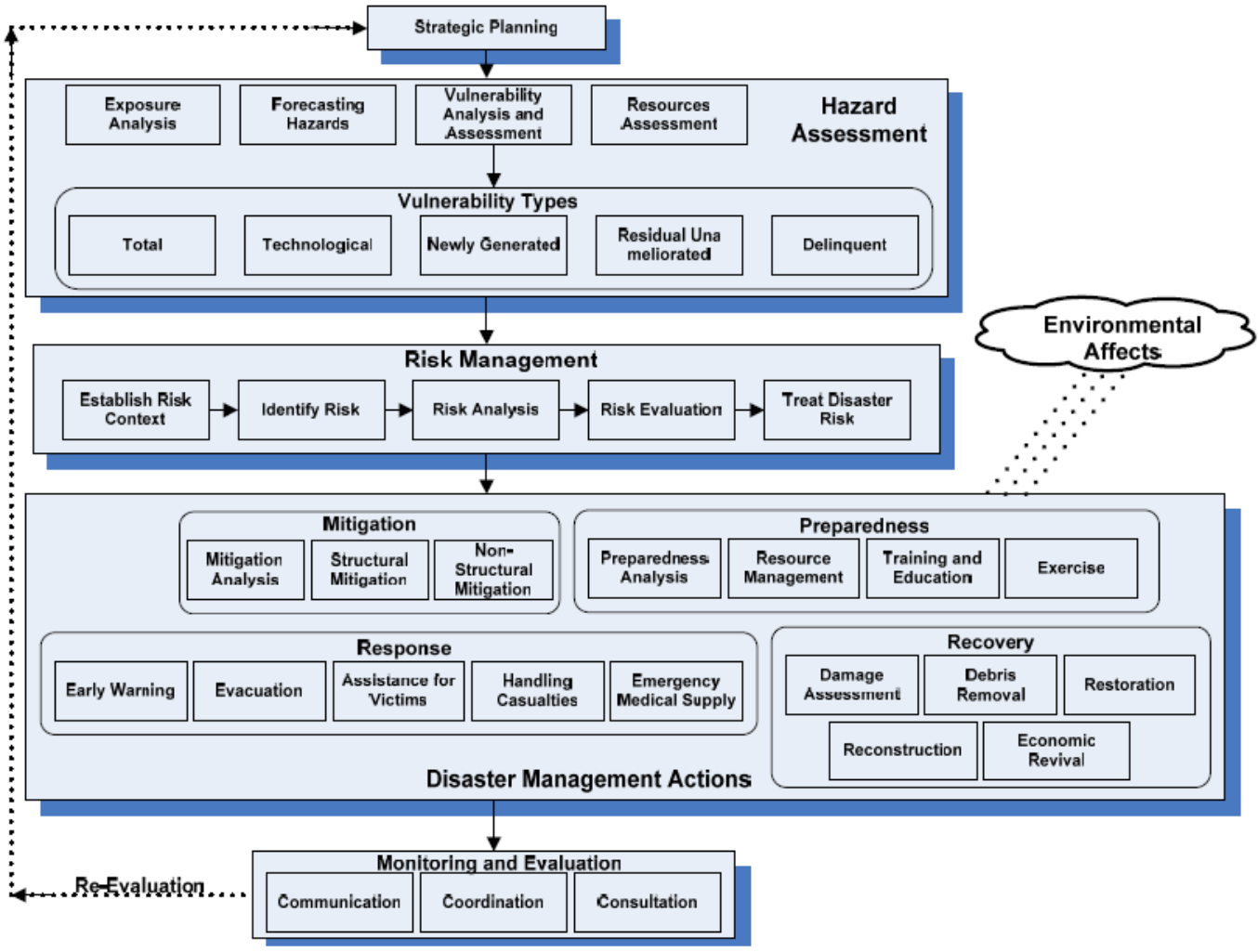

Figure 1. Comprehensive Disaster Management (Churilov et al., 2006)

It begins with strategic planning in disaster communication strategy management, including information exposure analysis, hazard prediction, vulnerability analysis and assessment, resource assessment, and disaster hazard assessment. Next, determine the vulnerability type categories, including total, technical, new general vulnerabilities, or others. The next stage is risk management, including preparation, mitigation, response, and recovery. After that, disaster management is implemented, and the last stage is monitoring and evaluation (Churilov et al., 2006).

Developing an effective communication strategy on preparedness and mitigation requires detailed information to reduce the risk of future disasters. Strategic planning for disaster includes the following stages:

1. Collecting information from disaster areas involving many interest groups such as the community, disaster management staff at the local level, volunteers, community leaders, and individuals.

2. Analyse information to identify needs and make decisions.

3. Information dissemination, sharing information internally and externally in various interest groups on time, and involving the public media.

Implementing a disaster communication strategy that optimizes new media and social media in Indonesia is evident in the practice of natural and non-natural disasters. In addition, the presentation of information regarding strategic planning is carried out on an ongoing basis, between one part and another.

\section{Natural Disasters}

Indonesia's position at the confluence of three Eurasian Continental, Indian-Australian Oceanic, and Pacific Oceanic plates make Indonesia familiar with natural disasters. Disaster risk management, both aspects of prevention and mitigation to recovery, are essential. Strategic planning is managed so that the steps taken can achieve optimal results. This section describes the planning for using new media and social media in the category of natural disasters.

Based on the initial conditions of the people in Merapi volcano areas have limited access to information. This condition is not only caused by the existence of infrastructure that is still minimal. The level of education of the community is low. Most of them only completed elementary-level 
education, and many did not even finish elementary school. Conditions change with the development and socio-economic capabilities of the community. The relatively high income from sand mining affects changes in people's life patterns. The existence of information media has begun to increase, and even some residents have used smartphones to share information. This infrastructure encourages the use of new media in disaster communication for Merapi.

If we trace media use in disasters, the Haiti earthquake (2010) marked the beginning of the use of new media in disaster situations and Tropical Cyclone Winston, which occurred in 2016. In Indonesia, using new media and social media in disaster communication began to be practiced in 2012.

The Haiti earthquake (2010) has become the beginning of new media in disaster situations and Tropical Cyclone Winston in 2016. In Indonesia, using new media and social media in disaster communication has also begun in 2012. The Mount Merapi disaster event through Jalin Merapi is an initial description of implementing new media and social media in disasters in Indonesia. This action was driven by the Trans Merapi Information Network or known as Jalin Merapi. This community was founded in 2006 as a bottom-up initiative of three community-based radio stations located around Mount Merapi, two community radio networks, and four local NGOs (Tasic, 2016).

Jalin Merapi is a social movement for disaster management in the community. The strategic planning carried out by the Jalin Merapi community aims to provide accurate information about the disaster conditions of Mount Merapi and find solutions to the problems of the community affected by the disaster. The steps taken are determining the relevant media, presenting media messages, and implementing plans related to media use.

In 2010 with the advancement of information and communication technology that is getting stronger, the actions taken by this community utilize media that are considered relevant and appropriate when the Mount Merapi eruption disaster occurs. New media used as information flow include SMS Gateway, Yahoo Messenger Chat, Website, streaming radio, webcam streaming, and social media including Twitter and Facebook (Mahaswari, 2012). According to Mahaswari's research analysis (2012), the new media can become an interpersonal liaison, both volunteers, organizational activists, and donors of funds, who exchange information about disasters that occur.

Various messages conveyed through new media and social media include data on the needs of victims, distribution of aid, maps of the distribution of posts, coordination of evacuation or disaster management, traffic situations, and monitoring of lahar flows. Specifically, social media, especially Twitter, uses messages with hashtags \#demandpengungsi and \#supplydaridonatur (Mahaswari, 2012). As a community social movement, Jalin Merapi's use of new media and social media is based on several reasons, such as the problems that occur as a form of national concern. In addition, the disaster that happened is an issue that requires action in fast handling. The need for accurate and reliable information is very much needed in this movement.

\section{Non-Natural Disaster}

In addition to natural factors, disasters can occur due to non-natural factors (Michael, 2010; Sena \& Kifle, 2006; Shibuya, 2020). Shibuya (2020) said disaster events include aspects of (1) technological and artificial hazards, (2) natural disasters, and (3) internal disturbances (e.g., acts of terrorism). A disaster may originate as natural or artificial and may be intentional or accidental (Beach, 2010). Corona Virus 2019 or better known as Covid-19, is a non-natural disaster. Covid-19 is a zoonotic disease caused by a coronavirus from China and is the third viral pandemic after SARS$\mathrm{CoV}$ and MERS-CoV (Mackenzie, 2020). Coronaviruses cause severe illness in humans and animals (Ahmad et al., 2020). The pandemic started in Wuhan in December 2019 and spread to the rest of the world, and it was designated a global disaster by the World Health Organization (WHO). In Indonesia, it was declared a national disaster on March 14, 2020 (Putsanra, 2020).

The COVID-19 outbreak has brought home almost the entire world's population in the process of controlling its spread. This condition is known as staying at home, working from home, studying from home, lockdown, and others in local and international languages. There are social distancing restrictions, and specific protocols are enforced in communicating and interacting. Behavioural patterns then shift by relying on new media.

Internet-based media allows people to stay connected in dialogues or forums, which is made more accessible by social media. The role of social media can educate the public and stimulate information about Covid-19 (Sampurno, M.B.T., T.C. Kusumandyoko, 2020). In addition, social media such as 
Facebook, Instagram, Twitter allow users to easily create and transmit content in the form of words, images, videos, and audio (Luttrell, 2019).

Indonesia's government tends to use new media during the Covid-19 period, including new media as the primary media to convey accurate information distribution. @BNPB_Indonesia is a social media account owned by the government through the National Disaster Management Agency (BNPB) to present news trusted by the public. The local government also uses new media as a website to update information such as "corona.jatengprov.go.id", which presents news both appeals, knowledge, and community service centers to connect with the Health Office.

One of the campaigns with the hashtag \#dirumahsaja is relatively easy to accept message by the public. This message has high persuasive power for most people. This message appears on several social media accounts built by activists and volunteers interested in the Covid-19 issue. For example, the Covid-19 Response (RC19) uses covid19.gamabox.id to mitigate the spread of Covid-19 in Indonesia. In addition, there are social media accounts Respond Covid-19 Indonesia on Facebook and @ responscovid19 on Instagram and Twitter.

Some studies even show that people tend to get information about Covid-19 from new media and social media. For example, Nurhajati, Sukandar, Octaviani's (2020) research shows that the uptake of conversation on the corona issue in Indonesia is dominated by new media, namely YouTube, Facebook, and then websites. Likewise, Mahestu and Asri's (2020) research shows that social media is the preferred source of information widely used by the public, including the government's official media, local government's applications, radio, and television.

\section{Toward New Media and Social Media in Disaster}

New media has various types of media platforms (McQuail, 2010). These new media and applications penetrated mass communication which had direct or indirect consequences on traditional mass media. The difference between new media and traditional media lies in the interactive level of media users, such as the ratio of the user's response to the message's sender, the level of user socialization, and the level of media attractiveness. The story of the socialization of new media is more individual rather than direct interaction and a high group of pleasure and privacy in new media (McQuail, 2010).

New media is a form of communication transformation between individuals, groups, and mass communication. New media changes in the production, distribution, and use of media involve technology, textual, conventional, and cultural. Some of the main terms in new media discourse include digital, hypertextual, virtual, and network (Lister et al., 2009). Bennett (2003) defines new media generally as referring to emerging information and communication technology applications such as cellular telephones, the internet, streaming technology, wireless networks, and the highquality publishing and information-sharing capacities of the World Wide Web.

Internet-based applications that are developing and widely used by new media users are social media. Social media refers to the activities, practices, and behaviors among communities of people who come together online to share information, knowledge, and opinions using the medium of conversation. The application builds on the ideologies and technologies fundamental to Web 2.0 and allows for creating and exchanging user-generated content (Kaplan \& Haenlein, 2010). In line with the thinking of Obar, J.A., and Wildman (2015), social media includes technologies that facilitate the creation, dissemination, and sharing of content through online communities and virtual networks. In addition, social media makes it possible to find information and several psychological benefits such as relieving stress through humors, knowing the condition of family and friends, mobilizing oneself, fostering a sense of community and emotional support that can motivate online communication (Cerase, 2018).

New media and social media seem to replace traditional media to communicate with the public during a crisis in disaster communication. The development of social media affects the way conventional media communication is received and distributed to the public. Social media is easier to accept. In its implementation, the content created by users is expected to provide a new source of information for those who handle disaster emergency management. During a disaster, people need accurate and reliable information so that its usefulness can overcome the uncertainty of the data. This purpose reaches through new media and social media. The currently developing media can influence the flow of information from government organizations to the public. Still, the public can participate in disseminating information and interacting more easily. 
The flow of transactional information is influenced by the characteristics of new media and social media, including (a) Interactivity, indicated by the ratio or user initiative to offers from information sources; (b) Society, there is a sense of personal contact with other people caused by the use of media; (c) Media richness, the extent to which the media can bridge different frames of reference, reduce ambiguity, give more cues, engage more senses, and become more autonomous-users control the content and use of media. (d) Independent can be for entertainment, pleasure; (e.) Privacy, related to the use of media and the selection of unique content according to the needs and desires of its users; (f) Personalization, the extent to which the content is personalized and has a uniqueness including in using the range (Lister et al., 2009).

Furthermore, based on the observation of the current conditions, the role of social media is increasing, especially with the slump in financial needs in traditional media. As an illustration, traditional media face a formidable challenge in taking advantage of the migration to the World Wide Web. Even in developed countries like the United States, some traditional media companies face difficulties due to changes in production circulation. Advertisers tend to move from newspaper to online advertisements, including television and radio. Transformation is evident in these conditions. This fact means that when optimizing new media and social media in disaster communication, this may be a reality that is rightly adapted to the movement of the user population.

\section{The Effectiveness of New Media and Social Media}

New media and social media are closely related to use and media satisfaction in disaster communication, namely the Uses and Gratification Theory. This theory states that people actively seek certain media and specific content to produce certain satisfaction or outcomes (Kant \& Gurevith, 2010). Media users can be active and rational people who can choose relevant media according to their needs. People as active audiences because they can examine and evaluate various media types in achieving communication goals. In this case, the Uses and Gratification theory is adopted for the context of new media and social media.

Furthermore, the use of media in the disaster communication cycle includes four separate moments, namely (a) Initial information about the disaster, (b) Reality checking, seeking information to understand the truth of the information; (c) transmit information or social interactions across individual social networks and disseminate it through interpersonal channels; (4) Building a frame, in which understanding about disasters is built together in a feedback loop between the media and the public (Cerase, 2018).

Typologically, interpreting the Uses and Gratification theory in disaster communication is defined through three stages of communication sequences before, during, and after the experience of using the media. Referring to Levy and Windhal (1984 in Cerase, 2018), orientation in use and satisfaction are obtained from each stage passed. First, selective exposure to experiences in using media to determine the channel used to meet their primary needs. Second is the exposure phase, meaning will emerge because of processing information collectively and individually and a more significant assessment and understanding of the available messages. Third, gratification is obtained, where content is used both for purposeful action orientation and to interact with others and increase the influence of individuals in their social networks.

The Uses and Gratification theory (Kant, Blumer, \& Gurevith, 2010) emphasizes that media users depend on information to fulfil their needs and goals. Three components influence the media to interact: the media, media users, and society. Adopting these theories on the use of new media and social media makes it possible to predict two possibilities of media user satisfaction in disasters, both gratification sough and gratification obtained. Gratification sought relates to the desired satisfaction when using the media based on the fulfilment of needs. Gratifications Obtained are several real satisfactions obtained by individuals to fulfil requirements in the use of media. When the difference between the desires and the satisfaction received is getting smaller, the media users will be more satisfied with its use.

In disaster communication, the use of new media and social media is based on active users. Users can access information and communication and choose the relevant media to meet their needs. There are several orientations when determining new media and social media as information channels, such as Jalin Merapi as a valid source of information. It is real-time and can also be used to share knowledge and empathy and even distribute social assistance. In line with Kant, Blumer, and Gurevith (2010), the determination of new media and social media is based on the goal of meeting 
user satisfaction. Likewise, the use of new media and social media during the Covid-19 pandemic, accurate, reliable, and real-time information in the form of images, videos, audio, text underpin the community in using this media.

Media use is not based on the media's changing attitudes and behavior but on how media users meet their personal and social needs. Characteristics of active audiences using media to achieve specific goals according to their needs. In a disaster situation and technological advances, it impacts changing the aspects of the media user community. In 2010 where the public increasingly consumed new media and social media, it became wise for Jalin Merapi to choose the new platform to reach the community.

The success of disaster communication conducted by Jalin Merapi with communication actions through new media and social media shows the effectiveness of using media. This reality is the starting point for utilizing this media in disaster communication. Even now, monitoring of disasters nationally by BNPB is informed through various accounts on social media platforms such as Instagram, Facebook, and Twitter with the username @BNPB_Indonesia (Fahriyani \& Harmaningsih, 2020) and also the bnpb.go.id. As in the non-natural disaster in Covid-19, these new media and social media are considered the primary news sources for the public to monitor the development of the outbreak in Indonesia.

In the case study of Merapi volcano and the Covid-19 pandemic, the effectiveness of using media is based on meeting the motives of the audience's needs. In the natural disaster of Merapi volcano, the main reason of the Jalin Merapi in using the media is to present correct and actual information regarding disaster emergencies. Information develops according to conditions in the disaster-prone area. It helps the coordination between institutions concerned with the Merapi disaster can be carried out correctly. Volunteers, organizational activists, and others can exchange information, provide needs according to conditions in the field. Donors can also obtain accurate information and help is relevant needs. It means that the diverse and heterogeneous audiences within the Jalin Merapi community are met with the desired motives.

Based on the effectiveness of media use in the Merapi volcano was proven again during the Covid-19 pandemic. Policy steps related to community protection implemented by the government, such as social distancing restrictions, change the general behaviour of the community. Working in the office, then completed at home. Social and physical activities are also carried out in the home environment. Behavioural shifts through the media. The availability of smartphones, media connected to the internet network is the dominant need for most people. In the disaster communication context, the mobilization of digital media implementation is increasing. Disaster management from planning, risk management, including mitigation, preparation, response, and recovery to evaluation, is supported by online communication media. The motive for fulfilling online needs is increasing and dominating people's behaviour.

In the second case study, the effectiveness of social media and new media is seen in several implementations of activities. The distribution of information from the government as a form of concern, protection policies, and various other important information is packaged in the mass media and online. Fulfilling the community's needs in the economic and health sectors relies on new media and social media. When the media fill in the audience's needs, the media is said to be effective.

Practical implementation based on this analysis hopes that media users can select suitable media to meet their needs because new media and social media development are diverse. As active users, people must mobilize beneficial social actions in line with the high potential for disasters in Indonesia and mobilize the community in general. Satisfaction will be obtained when media discrepancy is getting smaller in meeting the needs of disaster communication. Optimizing the use of new media and social media is a practical step in line with the shifting behaviour patterns of current media users. 


\section{CONCLUSION}

In summary, it is hoped that this research will contribute to themes related to disaster communication.

(a) The development of the media affects changes in strategic planning of disaster communication. In strategic planning, it is hoped that the results achieved are a success, so it is necessary to pay attention to several important things, including the characteristics of the community, media developments, and the relevant approach to using media.

(b) New media and social media have consequences for people's lives. In general, its presence shifts the role of traditional media. The development of new media in the early 2000 s influenced how disaster information was collected and distributed. Social media and new media are relevant to disaster management, both natural and non-natural disasters. The Merapi volcano disaster utilizes new media and social media to disseminate information, coordinate inter-agency, and raise funds. Likewise, in the national catastrophe of the Covid19 pandemic, new media and social media are the mainstays in disseminating information and distributing government policy related to public protection.

(c) The effectiveness of media use can be seen in the success of fundraising by the Jalin Merapi community. Coordination goes well and can be disseminated the community information in a precise and reliable manner. The mobilization of accurate information builds trust in donors and assists as needed. This success marks the effectiveness of using social media and new media for disaster communication in Indonesia country. Then underpin the attitude in nonnatural disasters in the form of the Covid-19 pandemic. New media and social media mediate disaster management. This media is a source of information related to the pandemic easily accessible by the public, replaces social interaction, makes it easier to fulfill consumer needs, and becomes the central infrastructure supporting the economic sector.

\section{REFERENCES}

Ahmad, T., Khan, M., Haroon, Musa, T. H., Nasir, S., Hui, J., Bonilla-Aldana, D. K., \& RodriguezMorales, A. J. (2020). COVID-19: Zoonotic aspects. Travel Medicine and Infectious Disease, 36, 101607. https://doi.org/10.1016/j.tmaid.2020.101607

Alexander, D. (2015). Disaster and Emergency Planning for Preparedness, Response, and Recovery. Oxford University Press USA. https://doi.org/DOI: 10.1093/acrefore/9780199389407.013.12

Bennett, W. L. (2003). New Media Power: The Internet and Global Activism. http://depts.washington.edu/ccce/assets/documents/pdf/newmediapower.pdf

Billy, M. (2020). The influence of dynamic organizations and the application of digital innovations to educational institutions in the world during the COVID-19 pandemic. SSRN. https://ssrn.com/abstract=3588233

Beach, M. (2010). Disaster Preparedness and Management. F. A. Davis Company.

Bradley, D. T., McFarland, M., \& Clarke, M. (2014). The Effectiveness of Disaster Risk Communication: A Systematic Review of Intervention Studies. PLoS Currents, August, 026. https://doi.org/10.1371/currents.dis.349062e0db1048bb9fc3a3fa67d8a4f8

Cerase, A. (2018). Re-Assessing the Role of Communication in the Aftermath of A Disaster: Case Studies And Lesson Learned in Antronico dan Marincioni. Natural Hazards and Disaster Risk Reduction Policies. Il Sileno Ed. Geographies of The Antropocene., 1(2), 213-242.

Churilov, L., Asghar, S. \& Alahakoon, D. (2006). A Comprehensive Conceptual Model for Disaster Management. Journal of Humanitarian Assistance.

Clinten, B. (2019). Jumlah Pengguna Facebook Tembus 2,4 Miliar. https://tekno.kompas.com/read/2019/10/31/14160067/jumlah-pengguna-facebook-tembus-24-miliar

Fahriyani, S., D. Harmaningsih, S. Y. (2020). Penggunaan Media Sosial Twitter untuk Mitigasi Bencana di Indonesia. Jurnal IKRA-ITH Humaniora, 4(2), 56-65.

Finau, G., et al. (2018). Social Media and Disaster Communication: A Case Study of Cyclone Winston. Pacific Journalism Review, 24(1), 123-137.

Frandsen, F. and Johansen, W. (2017). Strategic Communication. The International Encyclopedia of 
Organizational Communication.

Haddow, G. D., K. S. H. (2014). Disaster Communications in A Changing Media World. Elsevier.

Hafida, Siti Hadiyati Nur, B. S. and R. A. A. (2018). The effectiveness of community radio infrastructure to support disaster preparedness (case study of community radio in Merapi Volcano, Yogyakarta, Indonesia. MATEC Web Conference, 229(04004).

Hallahan, et al. (2017). Defining Strategic Communication. International Journal of Strategic Communication, 1(1), 3-35.

Harihar, A. (2015). No Title Social Media and Its Role in Disaster Management. http://www.business2community.com/social-media/social-media-role-disaster-management 01214144\#j133WzmEsrvUVJcq.97

Holdeman, E. (2016). Social Media in the Face of Disaster Response. https://www.govtech.com/em/emergency-blogs/disaster-zone/social-media-in-the-face-ofdisaster-response.html

Hua, J. dan R. S. (2020). Corona Virus (COVID-19) "Infodemic" and Emerging Issues through a Data Lens: The Case of China. International Journal of Environmental Research and Public Health, 17(2309), 1-12. https://doi.org/Doi:10.3390/ijerph17072309

Jayani, D. H. (2020). 10 Media Sosial yang Paling Sering Digunakan di Indonesia. https://databoks.katadata.co.id/datapublish/2020/02/26/10-media-sosial-yang-paling-seringdigunakan-di-indonesia

Kant, E, J.G.Blumer, and M. G. (2010). Uses and Gratification Theory. In Introducing Communication Theory: Analysis and Application. McGraw Hill.

Kaplan, A. M., \& Haenlein, M. (2010). Users of the world, unite! The challenges and opportunities of Social Media. Business Horizons, 53(1), 59-68. https://doi.org/10.1016/j.bushor.2009.09.003

Lestari, Puji, Agung Prabowo, dan A. W. (2012). Manajemen Komunikasi Bencana Merapi 2010 pada saat Tanggap Darurat. Jurnal Ilmu Komunikasi, 10(2), 173-197.

Liberati, A. (2009). The PRISMA Statement for Reporting Systematic Reviews and Meta-Analyses of Studies That Evaluate Health Care Interventions: Explanation and Elaboration. Annals of Internal Medicine, 151(4), W. https://doi.org/10.7326/0003-4819-151-4-200908180-00136

Lister, M., Dovey, J., Giddings, S., Kelly, K., \& Grant, I. (2009). New Media: A Critical Introduction. In Choice Reviews Online (2nd ed.). Routledge. https://doi.org/10.5860/choice.44-1949

Luttrell, R. (2019). Social Media: How to Engage, Share, and Connect. Rowman \& Littlefiel.

Mackenzie, J. S. and D. W. S. (2020). COVID-19: A Novel Zoonotic Disease Caused by A Coronavirus from China: What We Know and What We Don't. Microbiology Australia. https://www.ncbi.nlm.nih.gov/pmc/articles/PMC7086482/

Mahaswari, M. (2012). Jalin Merapi: Penggunaan Media Baru dan Gerakan Sosial Penanggulangan Bencana. Jurnal Komunikasi Indonesia, 1(2), 67-76.

Mahestu, G., T. M. A. (2020). Konklusi Survei Pandangan Masyarakat Terkait Wabah Covid-19. https://www.researchgate.net/profile/Gayes_Mahestu2

McQuail, D. (2010). Mass Communication Theory: An Introduction. SAGE.

Michael, B. (2010). Disaster Preparedness and Management. F.A. Davis Company.

Nurhajati, L., R. Sukandar, R.C. Octaviani, X. A. W. (2020). Perbincangan Isu Corona COVID-19 di Media Daring dan Media Sosial di Indonesia: Big Data Analysis. Lembaga Penelitian, Publikasi, dan Pengabdian Masyarakat.

Obar, J.A. and Wildman, S. (2015). Social Media Definition and The Governance Challenge: An Introduction to The Special Issue. Telecommunications Policy, 39(9), 745-750.

Pitt, Christine Sarah, dan E. T. (2017). Understanding Communication In Disaster Response: A Marketing Strategy Formulation And Implementation Perspective. J Public Affairs, 1-6. https://doi.org/10.1007/978-3-319-45596-9_235

Putsanra, D. V. (2020). Update Corona Indonesia: COVID-19 Bencana Nasional, Kasus Capai 117. https://tirto.id/update-corona-indonesia-covid-19-bencana-nasional-kasus-capai-117-eFq1

Qoidah, N. \& E. W. (2020). Manajemen Bencana Gunung Merapi Berbasis Masyarakat. Higeia Journal of Public Health Research and Development, 4(1).

Sampurno, M.B.T., T.C. Kusumandyoko, M. A. I. (2020). Budaya Media Sosial, Edukasi Masyarakat dan Pandemi COVID-19. Jurnal Sosial \& Budaya Syar-I., 7(6), 529-542.

Sena, L., \& Kifle, M. (2006). Disaster Prevention and Preparedness. In Ethopia Public Health Training Initiative (Vol. 1, Issue November). Jimma University. https://doi.org/10.1016/j.jes.2015.01.017 
Vol. 13 No. 2

Shibuya, Y. (2020). Social Media Communication Data for Recovery. In Social Media Communication Data for Recovery. https://doi.org/10.1007/978-981-15-0825-7

Snyder, H. (2019). Literature review as a research methodology: An overview and guidelines. Journal of Business Research, 104, 333-339. https://doi.org/10.1016/j.jbusres.2019.07.039

Tasic, J, S. A. (2016). Informational Capital and Disaster Resilience: The Case of Jalin Merapi. Disaster Prevention and Management, 25(3), 1-18.

Topno, P. N. (2016). Social Media An effective tool for Disaster Response. International Council on Social Welfare, July 2016, 28-31.

Victoria, L. (2002). Community Based Approaches to Disaster Mitigation. Paper Presented at Regional Workshop on Best Practices in Disaster Mitigation, Bangkok. https://www.preventionweb.net/Files/602_8370.Pdf

Wardyaningrum, D. (2019). Relations in the Communication Networks Centrality for Disaster Risk Reduction. Komunikator, 11(1). https://doi.org/10.18196/jkm.111016

WHO \& PAHO. (2020). Understanding the Infodemic and Misinformation in the Fight against COVID-19. https://iris.paho.org/bitstream/handle/10665.2/52052/Factsheetinfodemic_eng.pdf?sequence $=14$

Yates, D., \& Paquette, S. (2011). Emergency Knowledge Management and Social Media Technologies: A Case Study of the 2010 Haitian Earthquake. International Journal of Information Management, 31(1), 6-13. 